\title{
Ontology-based sentiment analysis for brand crisis detection on online social media
}

\author{
Quan Thanh Tho, Mai Duc Trung*
}

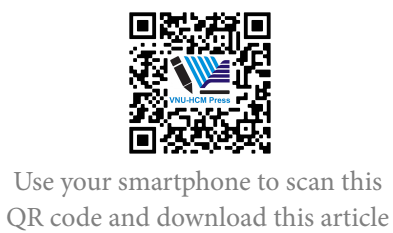

Computer Science and Engineering, Ho Chi Minh City University of Technology, VNU-HCM

\section{Correspondence}

Mai Duc Trung, Computer Science and Engineering, Ho Chi Minh City University of Technology, VNU-HCM

Email: mdtrung@hcmut.edu.vn

History

- Received: 28-7-2019

- Accepted: 29-8-2019

- Published: 27-10-2020

DOI : 10.32508/stdjet.v3iSI1.515

\section{Check for updates}

\section{Copyright}

(C) VNU-HCM Press. This is an openaccess article distributed under the terms of the Creative Commons Attribution 4.0 International license.

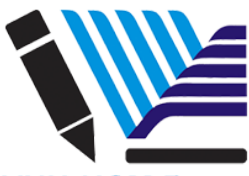

\begin{abstract}
Social media is emerging as a popular channel for online marketing. Nowadays, there more and more brands those are using social media to track and care for their brand health. Especially, social media is a source and also an important channel for brands to take care of their brands. On social media, things can move quickly due to viral information spread among the audience. Thus, a robust and automatic method for detecting crisis and even stop the crisis before it starts is urgently demanded.This paper discusses detection of brand crisis on online social media, i.e. when a brand is being suffered from unexpectedly high frequency of negative comments on online channels such as social networks, electronic news, blog and forum. In order to do so, we combined the usage of probabilistic model for burst detection with ontology-based aspect-level sentiment analysis technique to detect negative mention. The burst on online environment is a trendy topic that is rapidly growing recently, whereas the sentiment analysis process helps to identify the opinion of the audience regarding the brands. By combining domain knowledge captured in the ontology, we can make the analysis process focused on certain domains when needed. Also, the ontological concepts can also improve the accuracy of sentiment analysis at the aspect level.To evaluate the performance of our approach, we collect real data from online social media channels in Vietnam, which are provided by YouNet Media, a professional online data analysis company. Our experimental results show that the aspect-level sentiment analysis technique is extremely useful for detecting of negative mentions that related with the products and brands. Based on the achieved results, commercial products and platforms can be seriously considered.
\end{abstract}

Key words: Online crisis detection, burst detection, aspect-oriented sentiment ontology, sentiment analysis

\section{INTRODUCTION}

With the transition of information and communication technology (ICT) over the Internet, social networking has developed rapidly and become a powerful medium for dealing with social crises in realtime $^{1}$. In particular, social media offers potential methods to perceive and respond to emergencies ${ }^{2}$. For example, in the terrorist act in Paris on Friday, November 13, 2015, social networks become important in helping people to be aware of terrorist attacks and encouraging each other to locate safety shelter ${ }^{\mathrm{a}}$. In this article, we addressed a particular form of online emergency occurrence, known as a brand crisis, where a brand suffers from an abnormally high level of derogatory feedback on online platforms. Toyota ${ }^{b}$ and Domino Pizza ${ }^{c}$ are common examples in which online platforms provide successful means of enabling

${ }^{a}$ http://www.wired.com/2015/11/paris-attacks-parisians-use-po rteouverte-hashtag-to-seek-offer-safe-shelter/

${ }^{b}$ http://www.bsgco.com/work/cases/toyota-reputation-manage ment

${ }^{\mathrm{c}}$ http://cssc.uscannenberg.org/cases/v1/vlart6/ derogatory content to circulate rapidly as a viral. Besides that, this environment also helps the brand to successfully counteract a crisis through a range of techniques: (i) early warning or predicting of a crisis $^{3}$ and (ii) consumer input on a complicated social media landscape ${ }^{4}$.

In this paper, we proposed the new approach, which combined two techniques for handling the brand detection. We applied probabilistic model to detect burst as a trendy topic that is emerging recently.

Besides, we applied an approach of ontology-based sentiment analysis to detect burst that implies potential crisis of a brand.

\section{BURST IDENTIFICATION FOR CRISIS DETECTION}

Burst, or burst of activity, is a case that certain features are rising sharply in frequency, corresponding with the rising of a topic ${ }^{5}$. We review briefly this technique in the context of crisis detection on social network as follows.

Cite this article : Tho $\mathrm{Q} T$, Trung M D. Ontology-based sentiment analysis for brand crisis detection on online social media. Sci. Tech. Dev. J. - Engineering and Technology; 3(SI1):SI40-SI49. 
The crisis detection model on social network can be viewed as a probabilistic automaton $A$ with two states $C$ and $N$ (i.e. crisis and normal), corresponding to the cases of crisis occurring or not. Intuitively, the crisis can occur with brand when the number of negative mentions of the brand is increased suddenly on the online environment or social media in a certain considerable period. When $A$ is in state $N$, the number of negative mentions is emitted at a slow rate. When $A$ is in state $C$, the negative mentions are emitted at a faster rate. The cause that makes $A$ switch from state $N$ to $C$ or vice versa depending on the previous emissions and current state.

To illustrate this, let us consider the distribution of negative mentions of in Figure 1. In the first three days, the frequencies of negative mentions are quite low, making $A$ stay in state $N$, i.e. no crisis. In fourth day, the number of negative mentions is increased suddenly. However, A is still not switched from $N$ to $C$, implying an inference that it may not be a crisis, but an anomaly occurrence. From fifth day to seventh day, the negative mention frequencies are low again, and $A$ is still in state $N$. From the eighth day, the negative mention frequencies are gradually increased. Then, at ninth day, $A$ changed from state $N$ to $C$, implying the starting of crisis. $A$ stay at this crisis state from the ninth day to fourteenth day, due to the averagely high frequency of negative mentions. Note that although in the twelfth day, the negative mention frequency is decreased lower, but $A$ is still not change state, concluding this the crisis may only drop temporarily. From the fourteenth day, the negative mention frequencies decrease remarkably, resulting $A$ changing state to $N$ in the fifteenth, marking the end of the crisis.

Therefore, the sequence of states of $\mathrm{A}$ in those 15 consecutive days can be represented by the string "NNNNNNNNNCCCCCCN". The authors developed the traditional HMM model to accomplish this transition sequence ${ }^{5}$. The model is further enhanced in ${ }^{6}$ for better performance. The application of this approach in the time series data is presented by the work of Parikh et. $a l^{7}$. The real-data from electronic news and Twitter have been used to detect the burst ${ }^{8}$. In this paper, we continuously applied the algorithm ${ }^{6}$ to detect a crisis as a burst of negative mentions.

\section{SENTIMENT ANALYSIS AND COREFERENCE RESOLUTION}

In order to deploy burst detection model as previously discussed, one needs a mechanism to infer whether a mention is negative towards a brand or not. It involves sentiment analysis ${ }^{9}$, which is to research how computer can analyze the user opinions. One of the challenges of this task is to identify objects mentioned by the opinion. The difficulty lies on the fact that sometimes the objects are not directly mentioned, but implied by another means. We refer this case as the problem of coreference. Apart from the typical anaphoric coreference in linguistic, one must consider the aspect coreference, which occur when multiple aspects refer to the same entity, or one aspect is attribute of another aspect ${ }^{10}$. Let us consider the following statement, for instance.

(S1) I consider an iPhone 6S. Unlike Samsung S7, it is unfortunately not really affordable for students. However, the design looks nice and eye-catching.

In this example, in the second sentence, the pronoun it refers to iPhone $6 S$ in the previous sentence, making a case of anaphoric coreference. In the third sentence, design is really an attribute of $i$ Phone $6 S$, introducing a case of aspect coreference. The coreference resolution of both anaphora and aspect levels can be viewed as a new development trend of sentiment analysis. This problem obviously cannot be tackled without a domain knowledge capturing both aspect and sentiment relations.

In this paper, we develop a specific ontology known as Aspect-oriented Sentiment Ontology, capturing relations between aspects and sentiment terms on a certain domain. This ontology is combined to some other lightweight NLP techniques to solve the problem of coreference for sentiment analysis.

\section{A FRAMEWORK OF SENTIMENT ANALYSIS USING ONTOLOGY-BASED COREFERENCE RESOLUTION}

In Figure 2, we presented a framework for crisis detection, which include the following components.

- A Knowledge Base consists of the AspectOriented Sentiment Ontology capturing domain knowledge and Pattern Rules capturing some lightweight NLP rules for shallow processing of textual data.

- Sentiment Engine uses information captured in Knowledge Base to perform sentiment rating for each mention in the User Feeds. Resolution is handled as well by this engine.

- The Crisis Detection Automata to detect negative bursts, which implies potential crisis, from the analyzed results for the Sentiment Engine. 


\section{Normal (N) vs Crisis (C)}

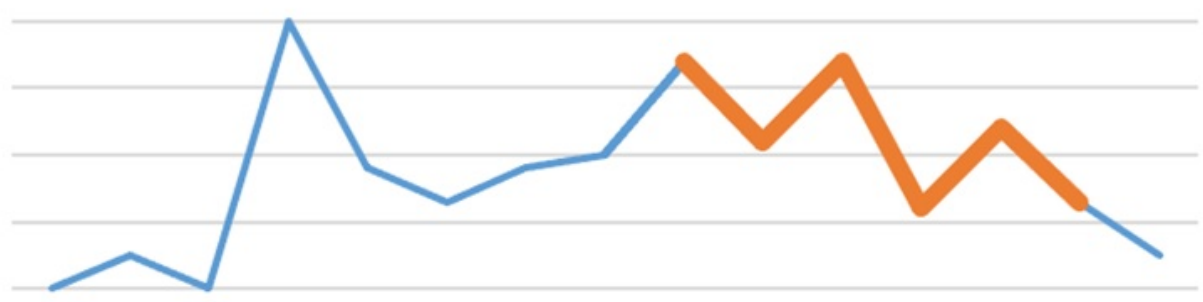

$\begin{array}{lllllllllllllll}\text { D1 } & \text { D2 } & \text { D3 } & \text { D4 } & \text { D5 } & \text { D6 } & \text { D7 } & \text { D8 } & \text { D9 } & \text { D10 } & \text { D11 } & \text { D12 } & \text { D13 } & \text { D14 } & \text { D15 }\end{array}$

$\begin{array}{lllllllllllllll}(N) & (N) & (N) & (N) & \text { (N) } & \text { (N) } & \text { (N) } & \text { (N) } & \text { (C) } & \text { (C) } & \text { (C) } & \text { (C) } & \text { (C) } & \text { (C) } & \text { (N) }\end{array}$

$\longrightarrow \operatorname{Normal}(\mathrm{N})=$ Crisis (C)

Figure 1: Illustration of crisisdetection.

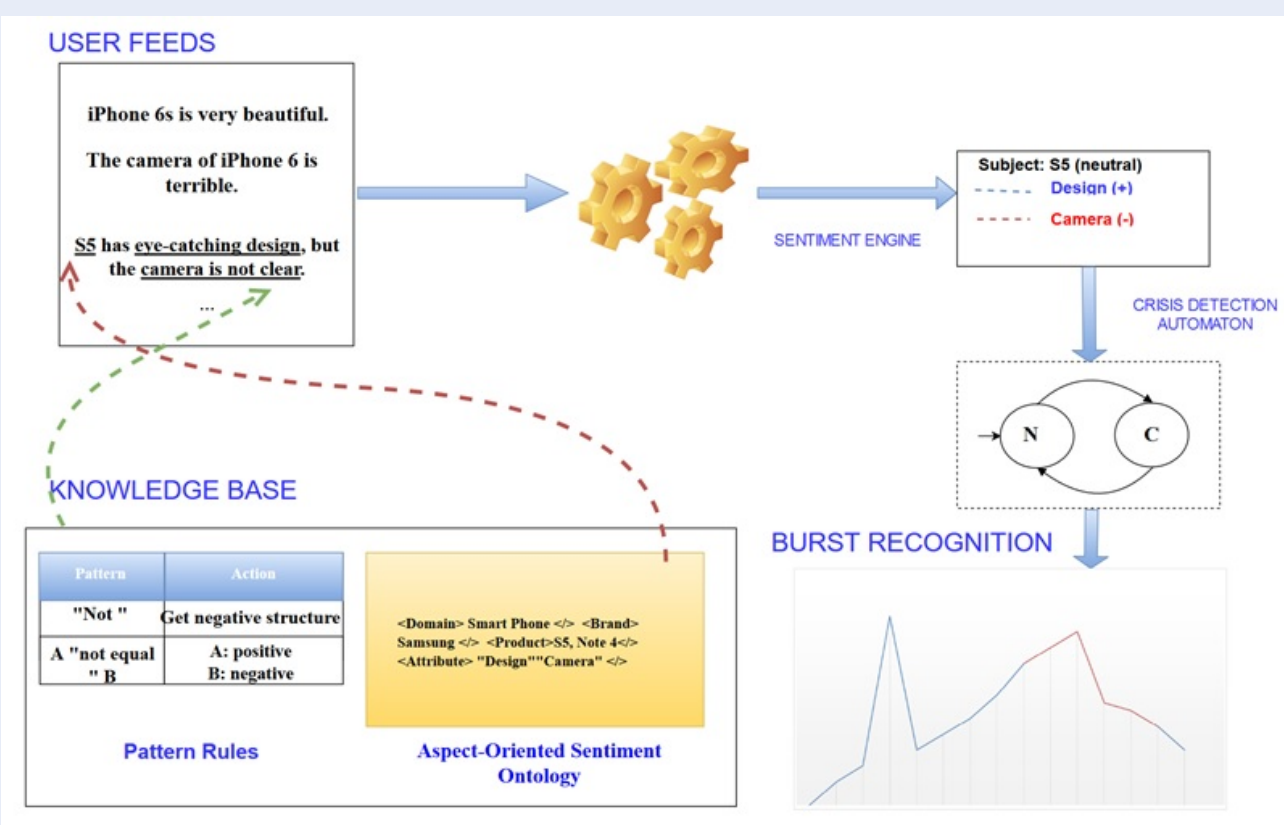

Figure 2: The framework for crisis detection 


\section{PROPOSED METHOD}

\section{Aspect-Oriented Sentiment Ontology}

Formal Definition

Definition 1 (Aspect-oriented Sentiment Ontology). An aspect of sentimental ontology $S_{O}$ is a pair of $\{C, R\}$; where $C=\left(C^{A}, C^{S}\right)$ is a collection of concepts based on two elements: $C^{A}$ is a collection of aspect definitions, and $C^{S}$ is a set of sentimental definitions; $R=\left(R^{T}, R^{N}, R^{S}\right)$ is a set of relationships composed of three components: $R^{N}$ is a set of non-taxonomic connections; $R^{T}$ is a set of taxonomic connections; $R^{S}$ is a sentimental connection. Each definition $c_{i}$ in $C$ symbolizes a group of objects, or instances, one of the same, indicated as an instance- of $\left(c_{i}\right)$. Each relationship $r_{i}\left(c_{p}, c_{q}\right)$ in $\mathrm{R}$ symbolizes a binary affiliation between definitions $c_{p}$ and $c_{q}$, and the examples of that connection indicated as instance-of $\left(r_{i}\right)$, are combinations of $\left(c_{p}, c_{q}\right)$ concept objects. In specific, a case of $r_{i}^{s}(a$,$) in R^{S}$ refers to a relationship between a feature $a \in A$ and the emotion term $\mathrm{s} \in S$.

Example 1. The Generic Ontology $G_{O}=\left\{\left(C^{A}, C^{S}\right)\right.$, $\left.\left(R^{T}, R^{N}, R^{S}\right)\right\}$ is a sentiment ontology where its components are endowed as the following Listing 1.

Listing 1 - The formal representation of Generic Ontology

$\mathrm{C}^{A}=\{$ “Thing” $\}$

$\mathrm{C}^{S}=\{$ “Sentiment Term", "Negative Term", "Positive

Term" $\}$

$\mathrm{R}^{N}=\{\}$

$\mathrm{R}^{T}=$ \{subconcept-of("Positive Term", "Sentiment

Term”), subconcept-of("Negative Term", "Sentiment Term")\}

$\mathrm{R}^{S}=\{$ mentioned-by(“Thing", "Sentiment Term”)

instances-of("Positive Term") = \{"like" $\}$

instances-of("Negative Term") = \{"hate" $\}$

Generally, $G_{O}$ includes one element of the definition of Thing, the examples of which may be any real-life idea. For example, Thing can be mentioned or implied by an Emotion Term, which may be either Positive Term or Negative Term. In this case, $G_{O}$ does not pose any example of term element, non-taxonomic or sentimental relationship; while two words "like" and "hate" are examples of positive term and negative term in sentimental definitions.

We focus on the notion of T-Box and A-Box to represent the ontology graphically. Practically, the T-Box describes the interaction of the concepts and the ABox explains the occurrences of the definitions. Figure 3 indicates the T-Box and A-Box of Generic Ontology $G_{O}$.

We also develop two separate sentimental connections for sentiment ontology in Figure 4, referred to as mentioned-by and implied-by. An aspect example $c$ may be mentioned-by a sentiment term $s$, implying that $c$ is either positive or negative, depending on if $s$ belongs to the Positive Term or Negative Term classes, respectively. Furthermore, implied-by is similar to mentioned-by but it has a more precise sense. An element of instance $c$ may be implied- by a sentiment word $s$, which means that $s$ is only relevant to $c$, not to other aspects. Thus, if $s$ appears in the textual statement $\vartheta$, it can be assumed that $c$ is also inferred in $\vartheta$ without explicit mention.

\section{Sentiment Analysis}

To use a lightweight NLP technique, the corresponding conceptual graph (CG) of this claim can be generated as shown in Figure 5. We have already introduced the methodology for constructing such a computational graph via a knowledge base ${ }^{12}$. Nevertheless, to carry out sentiment analysis, we should catch more complicated linguistic patterns, such as the non-phrase provided in Example 3. Each pattern contained in our NLP Knowledge Base is a Sentiment Phrasing Rule that is used to collect the pattern. The composition of the Sentiment Phrasing Rules is as follows.

Sentiment_Phrasing_Rule

\#pattern: the pattern of the sentiment phrases captured by this rules

\#sent_parts: the parts of the phrase expressing the sentiment

\#core_part: The part expresses the main sentiment trend in phrases.

\#core_word: used when we have multiple words in core parts

\#neg: Flag to indicate that it is a negative phrase or not.

Example 3. Let us consider the following rule:

Example_Sentiment_Rule_1

\#pattern: $(\backslash \mathrm{S}+/ \mathrm{N} \backslash \mathrm{s}+)+(\backslash \mathrm{S}+/ \mathrm{V} \backslash \mathrm{s}+)+\left(\backslash \mathrm{S}+/ \mathrm{A} \backslash \mathrm{s}^{*}\right)+$

\#sent_parts: [V,A]

\#core_part: V

\#neg: 0

The \#pattern of the rule is described by a regular expression (RE), conforming to the RE convention specified at http://regexpal.com/. Roughly speaking, one can read this rule as follows: "This rule applies for the sentence matching the following pattern: There is a noun $N$ in the sentence, then a verb $V$ after $N$, and then an adverb $A$ after $V$.";

The \#sent_parts specify that only $V$ and $A$ are necessary to infer the sentiment (meaning $N$ would bear no 


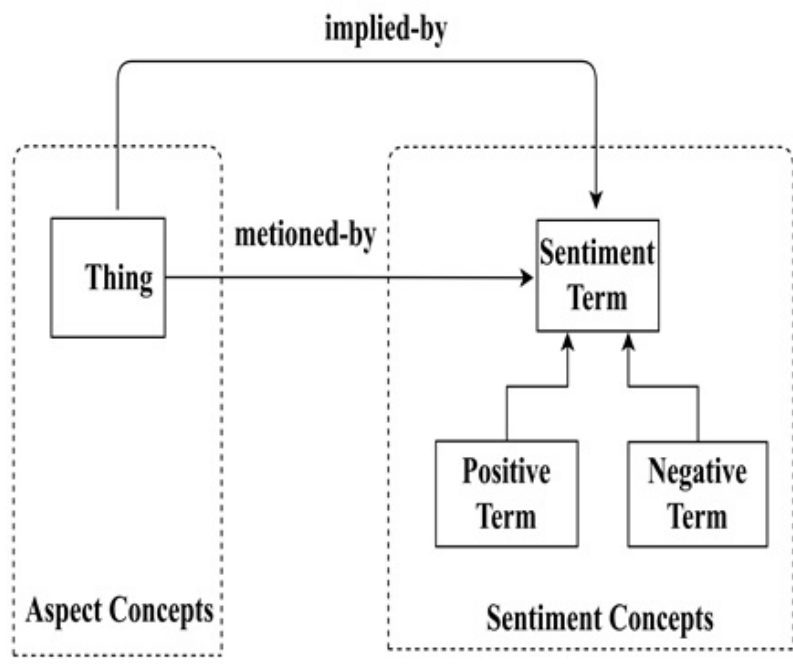

(a) The T-Box

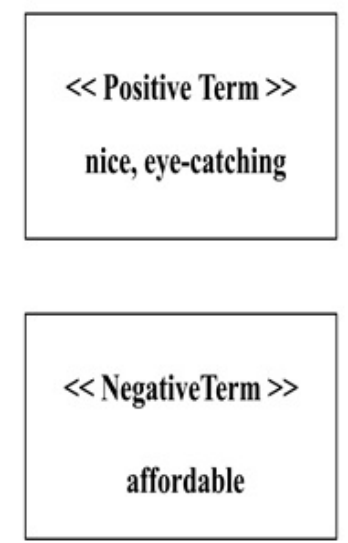

(b) The A-Box

Figure 3: An example of Generic Ontology ${ }^{11}$

sentiment opinion in this case; and \#core_part specifies that the main sentiment of this phrase can be inferred by $V$ ( $A$ will only be taken into account if we are unsure about the sentiment implication of $V$ ).

\section{EXPERIMENTAL RESULTS}

\section{Smartphone Knowledge Base}

To perform tests with the actual information, we have acquired from YouNet Media (YNM), an organization devoted to social listening and business research, actual customer analysis datasets on mobile products. Databases include 2809, 3098, and 365 negative, neutral, and positive references, overall, to 6 smartphone items. All in all, 1,782 positive terms and 1,469 negative terms are identified for the Smartphone realm. As a result, we have built a Mobile Ontology framework modeled by the Protégé framework, as shown in Figure 6.

\section{Crisis Alert System}

A crisis alert system is then developed by our method, as illustrated in Figure 7. The information is organized a "spike chart". Each "spike" shows a discussion phase. In the last spike due to the increasing amount of negative information is becoming higher, the system then changes the color of this spike to the lime for alerting.

\section{Experimental Result}

After that, we assessed the precision of our approach to sentiment analysis. We contrasted the performance of the different sentiment analysis techniques as follows.

- SEN-FULL: We have submitted our full structure.

- SEN-NO-ONT: In the system, we did not use Aspect-oriented Sentiment Ontology.

- SEN-NO-RULES: In the system, we did not use Sentiment Phrasing Rules.

- SVM: SVM was used for sentiment grouping, as this strategy was used by numerous related works.

- Delta tf.idf metrics' ${ }^{13}$ new findings were also used to achieve the optimum efficiency of the SVM technique.

Figure 8 indicates the percentage of precision when implementing these research techniques to the datasets obtained. We can find that in classic smartphones such as Nokia 220 or Philips E160, the precision performance of SEN-FULL and SEN-NOONT was more or less the same, as these versions are very old so their characteristics are not captured in the ontology. However, in other items where the related product characteristics have been adequately 


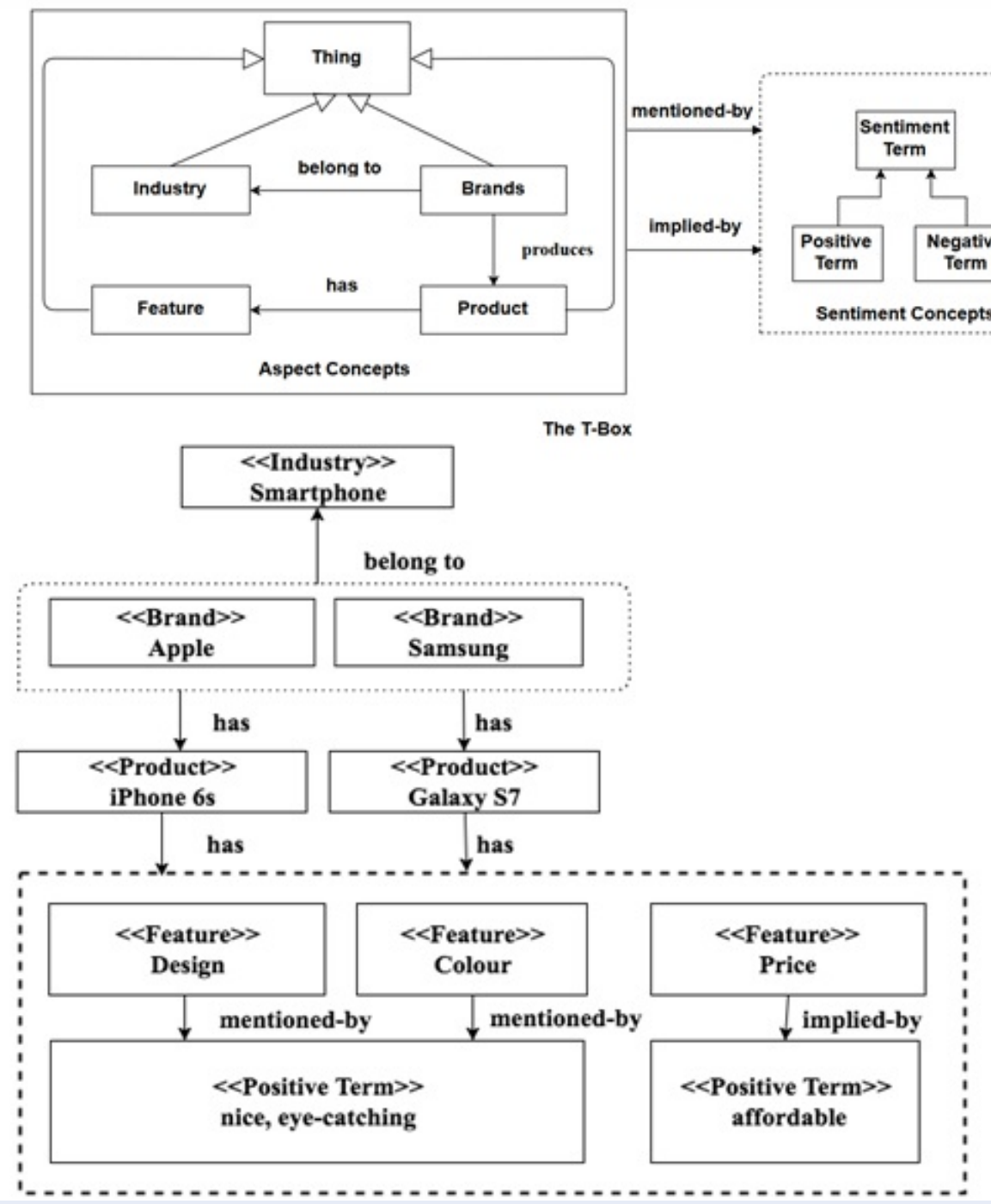

Figure 4: An example of Industry Ontology ${ }^{11}$

described in ontology, SEN-FULL has outperformed all other methods.

It is noteworthy that SVM could contend with SENNO-ONT in goods where neutral evidence was predominant, e.g. It's Huawei or LG Stylus. It can be clarified that the incidence level of sentiment phrases in neutral data was not high, so SVM could show its ability to identify insignificant samples (i.e. to identify samples without sentiment views). Nevertheless, once emotional phrases get huge, SVM has obtained low output due to the difficulty of language constructs, which might contradict the sense of sentiment. This aspect was mirrored in the fact that SENNO-RULES and SVM have essentially reached the same efficiency in all datasets.
Our sentiment analysis output is measured following the identification of non-neutral comparisons (i.e., negative and positive situations) from datasets. Undoubtedly, the collection of sentimental terms (both positive and negative) plays a key part in this mission. If we do not use any emotion term, we will not be able to distinguish any non-neutral situations. However, if we use the entire range of emotion terms, we can find the maximum number of non-neutral instances. It also raises the risk of false-positive confirmation (i.e. neutral reference is labeled as positive or negative). Thus, in this test, we differ the scale of the term of sentiment collection from blank to maximum size. After that, we measure the output of the sentiment analysis at each change point. The findings are indicated 


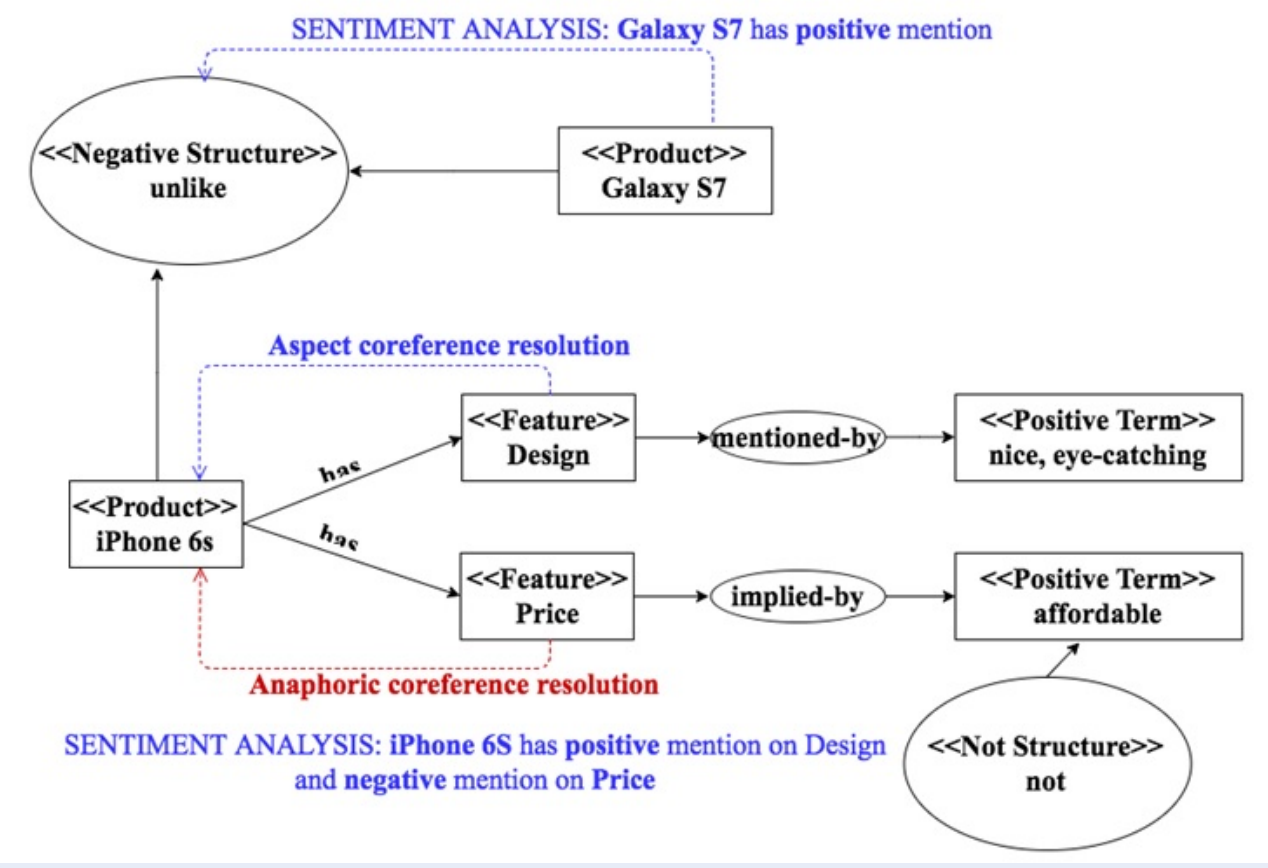

Figure 5: An example of sentiment analysis on conceptual graph

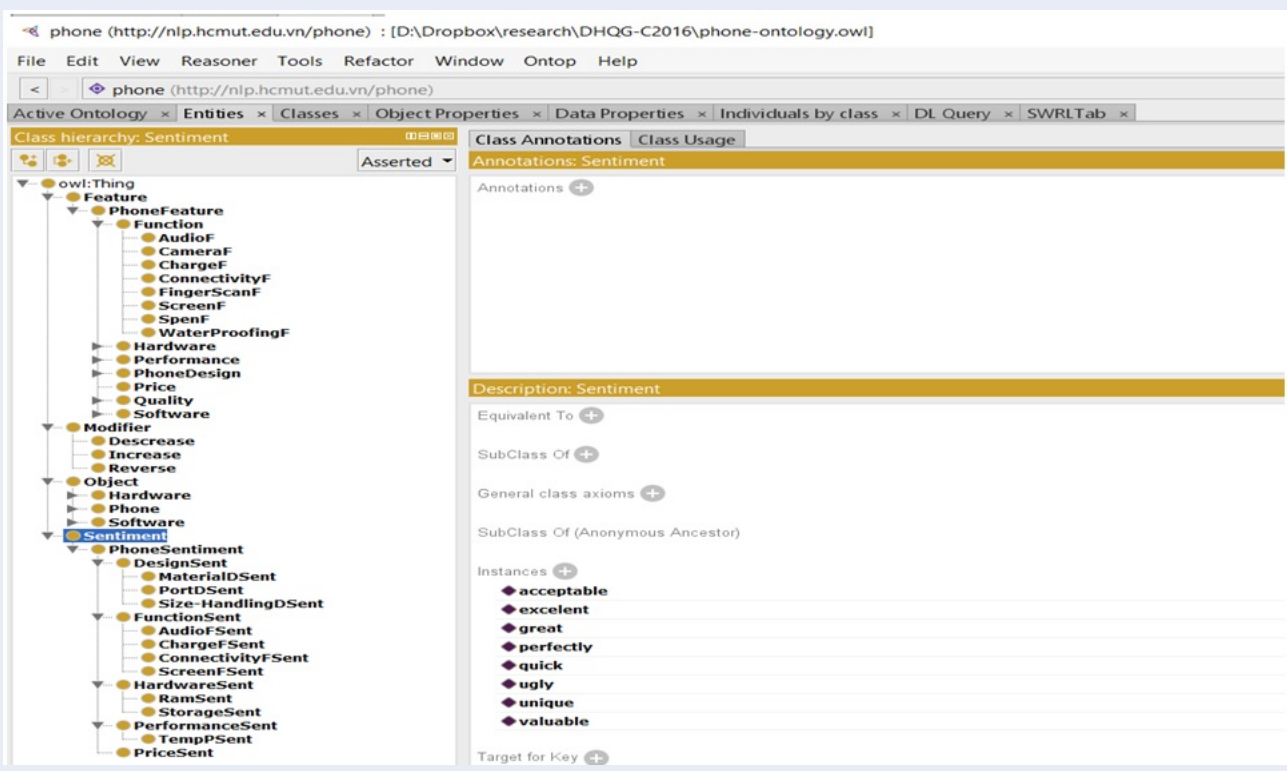

Figure 6: The Smartphone Ontology developed by Protégé 


\section{Total: 6 alerts}

16 hours ago

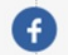

Spike for HPV

1000

500

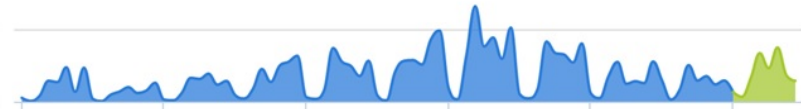

Jul 02, 2016 00:00Jul 04, 2016 00:00Jul 06, 2016 00:00Jul 08, 2016 00:00 Jul 10, 2016 00:00Jul 12, 2016 00:00

Figure 7: Spike chart show potential crisis

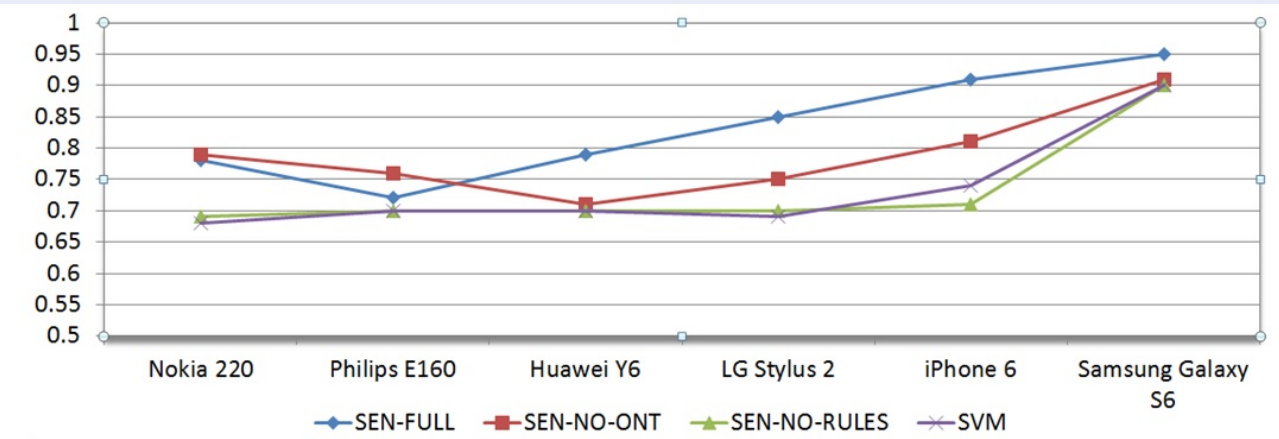

Figure 8: Accuracy performance of sentiment analysis strategies

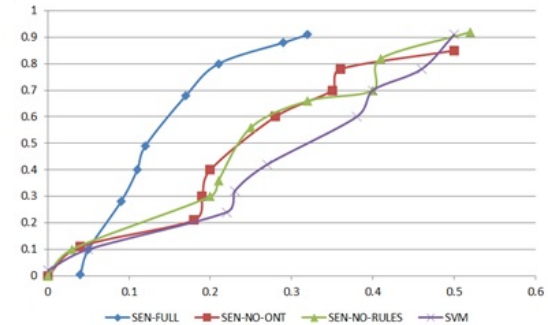

(a) ROC curves on Nokia 220

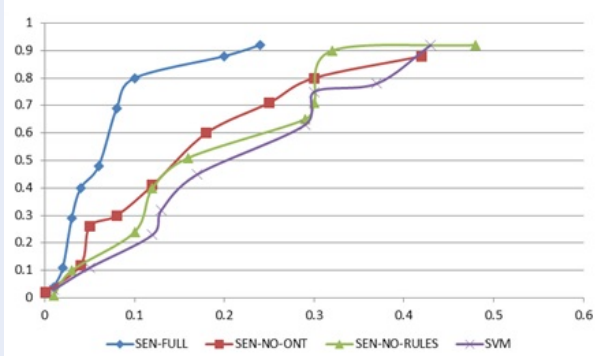

(c) ROC curves on $i$ Phone 6

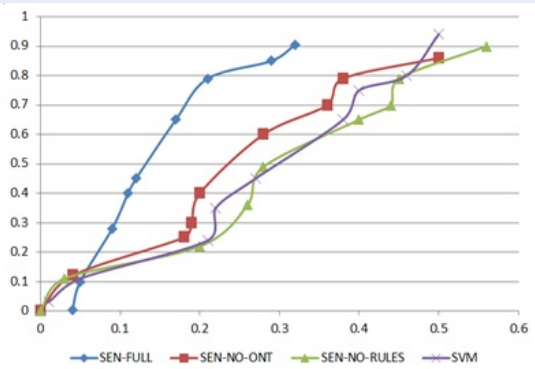

(b) ROC curves on LG Stylus 2

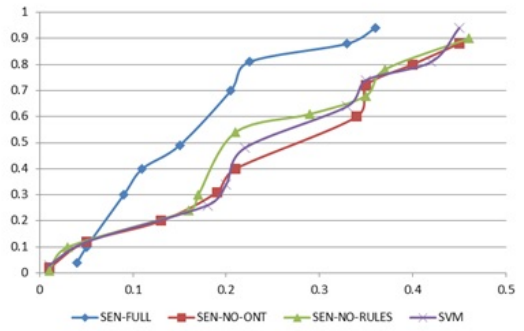

(d) ROC curves on Samsung $S 7$

Figure 9: Accuracy performance of sentiment analysis approaches 
by the respective ROC curves as shown in Figure 9. As stated, sentiment analysis methods included in our studies produce surprisingly great results as the areas covered by their ROC curves are significantly greater than the value of 0.5 (i.e. the area affected by a random classification). CSS FULL usually does higher than the majority of the three other ways.

\section{DISCUSSION}

Brand crisis detection has been an emerging issue nowadays with the advancement of social media. However, how to define a "crisis" formally, in order to be processed automatically in computing systems remains a challenging system. In this paper, this problem is addressed by a mathematical model of buzz, combined with the capability of knowledge representation by ontology. The performance of this proposal has been experimented, but its impact on real data still needs to be further explored.

\section{CONCLUSION}

In this article, we address the tracking of brand crisis by integrating burst identification strategies and ontological sentiment analysis. Then, we propose a general framework for this purpose. Under this system, domain ontologies, described as Aspect-oriented Sentiment Ontology, are paired with unique linguistic guidelines, described as Sentiment Phrasing Rules, to effectively facilitate sentiment ratings in online references. Our studies on actual databases from real media networks have obtained positive results.

\section{LIST OF ABBREVIATION USED}

ICT: Information and communication technology

CG: Conceptual Graph

RE: Regular Expression

HMM: Hidden Markov Model

YNM: YouNet Media

SVM: Suport Vector Machine

NLP: Natural Language Processing

\section{CONFLICT OF INTEREST}

The authors hereby guarantee that there is no conflict of interest in the publication of the article.

\section{AUTHOR CONTRIBUTION}

Associate Professor Quan Thanh Tho conceived of the presented idea, developed the theory and carried out the experiment. In addition. Associate Professor Quan Thanh Tho wrote the manuscript with support from Mr Mai Duc Trung.

\section{REFERENCES}

1. Middleton SE, Middleton L, Modafferi S. Real-time crisis mapping of natural disasters using social media. IEEE Intelligent Systems. 2014;29(2):9-17. Available from: https://doi.org/10. 1109/MIS.2013.126.

2. Yin J, Cameron MA, Power R, Robinson B. Emergency situation awareness from twitter for crisis management. In Proceedings of the 21st International Conference on World Wide Web ACM. 2012;p. 695-698. PMID: 22774929. Available from: https://doi. org/10.1145/2187980.2188183.

3. Zhao Z, Resnick P, Mei Q. Enquiring minds: Early detection of rumors in social media from enquiry posts. In Proceedings of the 24th International Conference on World Wide Web ACM . 2015;p. 1395-1405. Available from: https://doi.org/10.1145/ 2736277.2741637.

4. Maynard D, Gossen G, Funk A, Fisichella M. Should I care about your opinion? Detection of opinion interestingness and dynamics in social media. Future Internet. 2014;6(3):457-481. Available from: https://doi.org/10.3390/fi6030457.

5. Kleinberg J. Bursty and hierarchical structure in streams. Data Mining and Knowledge Discovery. 2003;7(4):373-397. Available from: https://doi.org/10.1023/A:1024940629314.

6. Zhang X. Fast algorithms for burst detection (Doctoral dissertation, Courant Institute of Mathematical Sciences New York). 2006;.

7. Parikh N, Sundaresan N. Scalable and near real-time burst detection from eCommerce queries. In Proceedings of the 14th ACM SIGKDD international conference on Knowledge discovery and data mining ACM . 2008;p. 972-980. Available from: https://doi.org/10.1145/1401890.1402006.

8. Koike D, Takahashi Y, Utsuro T, Yoshioka M, Kando N. Time Series Topic Modeling and Bursty Topic Detection of Correlated News and Twitter. In IJCNLP. 2013;917(921).

9. Liu B. Sentiment Analysis and Opinion Mining. Morgan \& Claypool Publishers. 2012;.

10. Padmaja S, Fatima S. Opinion Mining and Sentiment Analysis - An Assessment of Peoples' Belief: A Survey. International Journal of Ad hoc, Sensor \& Ubiquitous Computing. 2013;4(1):21-33. Available from: https://doi.org/10.5121/ ijasuc.2013.4102.

11. Le TT, Vo TH, Mai DT, Quan TT, Phan TT. Sentiment Analysis Using Anaphoric Coreference Resolution and Ontology Inference. In International Workshop on Multi-Disciplinary Trends in Artificial Intelligence Springer, Cham. 2016;p. 297-303. Available from: https://doi.org/10.1007/978-3-319-49397-8_ 26.

12. Quan TT, Hui SC. Ontology-based natural query retrieval using conceptual graphs. In Pacific Rim International Conference on Artificial Intelligence Springer Berlin Heidelberg. 2008;p. 309-320. Available from: https://doi.org/10.1007/978-3-54089197-0_30.

13. Martineau J, Finin T. Delta TFIDF: An Improved Feature Space for Sentiment Analysis. ICWSM. 2009;9:106. 


\title{
Phân tích cảm xúc dựa trên bản thể học cho việc phát hiện khủng hoảng thương hiệu trên truyền thông mạng xã hội trực tuyến
}

\author{
Quản Thành Thơ, Mai Đức Trung*
}

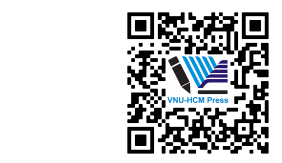

Use your smartphone to scan this

QR code and download this article

Khoa Khoa học và Kỹ thuật Máy tính, Trường Đại học Bách khoa,

$Đ H Q G-H C M$

\section{Liên hệ}

Mai Đức Trung, Khoa Khoa học và Kỹ thuât Máy tính, Trường Đại học Bách khoa, ĐHQG-HCM

Email: mdtrung@hcmut.edu.vn

Lịch sử

- Ngày nhận: 28-7-2019

- Ngày chấp nhận: 29-8-2019

- Ngày đăng: 27-10-2020

DOI :10.32508/stdjet.v3iSI1.515

\section{Check for updates}

\section{Bản quyền}

๑ ĐHQG Tp.HCM. Đây là bài báo công bố mở được phát hành theo các điều khoản của the Creative Commons Attribution 4.0 International license.

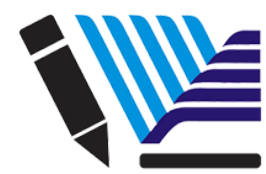

VNU-HCM Press

\section{TÓM TẮT}

Phương tiện truyền thông mạng xã hội đang nổi lên như một kênh phổ biến cho việc tiếp thị trực tuyến. Ngày nay, ngày càng có nhiều thương hiệu đang sử dụng phương tiện truyền thông mạng xã hội để theo dõi và quan tâm đến thương hiệu của họ. Đặc biệt, mạng xã hội là một nguôn và cũng là một kênh quan trọng để các thương hiệu quan chú ý tới thương hiệu của họ. Trên mạng xã hội, mọi thứ có thể làn truyền nhanh chóng do thông tin phát tán giữa nhung người sử dụng. Do đó, một phương pháp mạnh mẽ và tự động để phát hiện khủng hoảng và thậm chí ngăn chặn khủng hoảng trước khi nó bắt đầu xảy ra. Bài báo cáo này thảo luận về việc phát hiện khủng hoảng thương hiệu trên phương tiện truyền thông mạng xã hội trực tuyến, nghĩa là khi một thương hiệu đang bị tần suất bình luận tiêu cực cao đột biến trên các kênh trực tuyến như mạng xã hội, tin tức điện tử, blog và diễn đàn. Để thực hiện việc này, chúng tôi đã kết hợp việc sử dụng mô hình xác suất để phát hiện sự bùng nổ (burst) với kỹ thuật phân tích cảm xúc ở mức khía cạnh dựa trên bản thể học (ontology) để phát hiện các đề cập tiểu cực. Sự bùng nổ trên môi trường trực tuyến là một chủ đề hợp thời đang phát triển nhanh chóng gần đây, trong đó quá trình phân tích cảm xúc giúp xác định ý kiến của người dùng liên quan đến các thương hiệu. Bằng cách kết hợp miền kiến thức (domain knowledge) được thu thập trong bản thể học (ontology), chúng ta có thể làm cho quá trình phân tích tập trung vào một số miền nhất định khi cần. Ngoài ra, các khái niệm bản thể hoc (ontological concepts) cũng cải thiện tính chính xác của phân tích cảm xúc mức khía cạnh. Để đánh giá hiệu quả của phương pháp của chúng tôi, chúng tôi thu thập dữ liệu thực từ các kênh truyền thông mạng xã hội trực tuyến tại Việt Nam, được cung cấp bởi công ty YouNet Media, một công ty chuyên phân tích dữ liệu trực tuyến. Kết quả thực nghiệm của chúng tôi cho thấy kỹ thuật phân tích cảm xúc mức khía cạnh cực kỳ hữu ích để phát hiện các đề cập tiêu cực liên quan đến các sản phẩm và thương hiệu. Dựa trên kết quả đạt được, các sản phẩm và nên tảng thương mại có thể được xem xét nghiêm túc.

Từ khoá: Phát hiện khủng hoảng trực tuyến, Phát hiện bùng nổ, Bản thể học cảm xúc hướng khía cạnh, phân tích cảm xúc
Trích dẫn bài báo này: Thơ $Q T$, Trung $M D$. Phân tích cảm xúc dựa trên bản thể học cho việc phát hiện khủng hoảng thương hiệu trên truyền thông mạng xã hội trực tuyến. Sci. Tech. Dev. J. - Eng. Tech.; 3(SI1):SI40-SI49. 